\title{
Economic (Benefit Cost Ratio) Status of Summer Pearlmillet at Different NPK Levels
}

\author{
Neha*, Gautam Ghosh, Preeti Choudhary and Shobha Kumari \\ Department of Agronomy, Sam Higginbottom Institute of Agriculture, Technology and \\ Sciences, (Formerly Allahabad Agricultural Institute), (Deemed to-be-University), \\ Allahabad - 211007 (U.P), India \\ *Corresponding author
}

\section{A B S T R A C T}

\section{Keywords}

Pearlmillet, Level of NPK, Boron, Growth, Yield and Benefit Cost Ratio.

Article Info

Accepted: 17 May 2017 Available Online: 10 June 2017
A field experiment was conducted during Zaid season, 2015 at the Crop Research Farm, Department of Agronomy, SHIATS, and Allahabad (U.P.) to conducted Economics statues of summer pearlmillet (Pennisetum glaucum L.) hybrids to different levels of nitrogen. Among the response of different hybrids to levels of nitrogen, treatment T9 i.e., V3 + 100:45:45 kg ha ${ }^{-1} \mathrm{NPK}$, recorded maximum grain yield $\left(3.72 \mathrm{t} \mathrm{ha}^{-1}\right)$, straw yield $\left(6.98 \mathrm{t} \mathrm{ha}^{-1}\right)$, protein content $(13.43 \%))$ and harvest index $(36.15 \%)$. Whereas the lowest value in terms of plant height $(164.47 \mathrm{~cm})$, dry weight $(40.80 \mathrm{~g})$, grain yield $\left(2.47 \mathrm{t} \mathrm{ha}^{-1}\right)$ and straw yield $\left(4.62 \mathrm{t} \mathrm{ha}^{-1}\right)$ was observed in the treatment T1 i.e., $\mathrm{V} 1+80: 45: 45$ $\left.\mathrm{kg} \mathrm{ha}^{-1} \mathrm{NPK}\right)$. The highest gross return $\left(78795.00 \mathrm{ha}^{-1}\right)$, net return $(57222.00$ $\mathrm{ha}^{-1}$ ) and benefit cost ratio (2.65) were registered in treatment T11 i.e., N3 $(20: 60: 20 \mathrm{NPK})+0.2 \%$ foliar spray of borax at 35DAS (pre-flowering). Whereas the lowest value $\left(48925.50 \mathrm{ha}^{-1}\right),\left(30075.50 \mathrm{ha}^{-1}\right)$ and (1.59) respectively in the treatment T1 i.e., N1 (20:40:20 NPK).

\section{Introduction}

Pearlmillet [Pennisetum glaucum (L.)] is largely grown for grain and fodder purpose under those situations where other crops generally fail. Pearlmillet as a food crop is limited to the developing countries in Asia, and particularly in Africa and ranked sixth in the world following rice, wheat, corn, barley and sorghum (Anonymous, 2010-11). The important pearlmillet growing countries are India, China, Nigeria, Pakistan, Sudan, Egypt, Arabia, and Russia. It is estimated that over $95 \%$ of pearlmillet production is used as food, the reminder being divided between animal and poultry feed (7\%), other uses (seed, bakery products, snacks, etc.) and waste. The genus Pennisetum is distributed throughout the tropics and subtropics of the world. It includes about 140 species, one In India, pearlmillet is popularly known as Bajra, and it is the fourth most important cereal crop after rice, wheat and sorghum. It has the greatest potential among all the millets. Annual planting area of the country under pearlmillet is 9.5 million hectares producing nearly 10.1 
million tonnes of grains with productivity of $10.44 \mathrm{q} \mathrm{ha}^{-1}$ (Economic Survey of India, 2011). The major producing states are Rajasthan (46\%), Maharashtra (19\%), Gujarat (11\%), Uttar Pradesh (8\%) and Haryana (6\%), (Sonawane et al., 2010). The nutrient content of pearlmillet compares very well with other cereals and millets. It has high protein content with slightly superior amino acid profile. Pearlmillet grain contains 13-14 per cent protein, 5-6 per cent fat, 74 per cent carbohydrate and 1-2 per cent mineralsThe probable reasons for recording higher stature of growth attributes viz., plant height, leaf area index, dry matter production and number of tillers $\mathrm{m}^{-2}$ was observed in different varieties due to increased levels of nitrogen. While all these parameters were at their lowest value with no nitrogen application. Naik et al., (1995) and Basavarajappa et al., (2002) and also similar finding observed in pearlmillet by AICRP Forage Crops (2006).

\section{Materials and Methods}

Field experiment was conducted during Zaid season 2015 at Crop Research Farm, Sam Higginbottom Institute of Agriculture, Technology and Sciences (Deemed-to-beUniversity) Allahabad. The experimental site is located at $25057 \mathrm{~N}$ latitude, $87019 \mathrm{E}$ longitude and at an altitude of above mean sea level. The soil of the experimental area was sandy loam with moderately alkaline $\mathrm{pH}$; low in organic carbon $(0.32 \%)$ and available $\mathrm{N}$ (188.30 kg ha $\left.{ }^{-1}\right)$, available P (34.50 kg ha $\left.{ }^{-1}\right)$ and available $\mathrm{K}\left(87.00 \mathrm{~kg} \mathrm{ha}^{-1}\right)$ during zaid 2015 respectively.

A recommended pearlmillet variety (Pro Agro 9444, Ganga kaveri 1044 and Pioneer 86M 32) was chosen for the study. The experiment was laid out in Randomized Block Design (RBD) with two factor different levels of Nitrogen and three improved Varieties with nine treatments combination on a plot size of $3 \times 3 \mathrm{~m}^{2}$. Before sowing, line were formed in the field as the spacing in treatments. Pearlmillet was sown in line and covered with the soil. Pearlmillet seeds were hand dibbled. The total quantity of nitrogen, phosphorus and potassium as per treatment in the form of two split application are applied, one at basal and the second application at top dressing.

All the agronomic practices were carried out uniformly to raised the crop. For taking data on yield and yield components on pearlmillet five plants were selected randomly in each plot. Cost of cultivation, gross return, net return and benefit cost ratio was worked out to evaluate the economics of each treatment, based on the existing market prices of inputs and output. The Cost of Cultivation ( $\mathrm{ha}^{-1}$ ) for each treatment was work out separately, taking

\section{The Gross return $\left(\mathrm{ha}^{-1}\right)$ from each treatment was calculated}

Gross return $\left(\mathrm{ha}^{-1}\right)=$ Income from grain + income from stover

Net return $\left(\mathrm{ha}^{-1}\right)$

The net profit from each treatment was calculated separately, by using the following formula

Net return $=$ Gross return $\left(\mathrm{ha}^{-1}\right)-$ Cost of cultivation $\left(\mathrm{ha}^{-1}\right)$

\section{Benefit cost ratio}

The benefit cost ratio was calculated using the following formula

Benefit cost ratio $=\frac{\text { Gross return }\left(\mathrm{ha}^{-1}\right)}{\text { Total cost of cultivation }\left(\mathrm{ha}^{-1}\right)}$

\section{Results and Discussion}

Observations regarding the response of different levels of phosphorus and frequency 
of boron levels on economics of greengram are given in tables $1-4$.

\section{Grain yield ( $\left.\mathrm{t} \mathrm{ha}{ }^{-1}\right)$}

The result revealed that there was significant difference between different treatments and maximum grain yield $\left(3.72 \mathrm{t} \mathrm{ha}^{-1}\right)$ was observed by the application in T9 i.e., V3 + 100:45:45 kg ha ${ }^{-1}$ NPK, whereas the lowest value $2.47 \mathrm{t} \mathrm{ha}^{-1}$ was observed in treatment $\mathrm{T} 5$ i.e., $\mathrm{V} 2+90: 45: 45 \mathrm{~kg} \mathrm{ha}^{-1} \mathrm{NPK}$ and $\mathrm{T} 1$ i.e., $\mathrm{V} 1+80: 45: 45 \mathrm{~kg} \mathrm{ha}^{-1}$ NPK. And these are partially supporting by Tiwana and Puri (2005). However, treatment, T3 i.e., V1 + 100:45:45kg ha $\mathrm{kPK}^{-1}$ T6 i.e., V2 +
100:45:45 $\mathrm{kg} \mathrm{ha}^{-1}$ NPK was found statistically at par with T9 i.e., V3 + 100:45:45 kg ha ${ }^{-1}$ NPK.

\section{Straw yield $\left(\mathrm{t} \mathrm{ha}^{-1}\right)$}

The result revealed that there was significant difference between different treatments and maximum straw yield $\left(6.98 \mathrm{t} \mathrm{ha}^{-1}\right)$ was observed by the application in $\mathrm{T} 9$ i.e., $\mathrm{V} 3+$ 100:45:45 kg ha ${ }^{-1} \mathrm{NPK}$, whereas the lowest value $4.62 \mathrm{t} \mathrm{ha}^{-1}$ was observed in treatment $\mathrm{T} 1$ i.e., V1 + 80:45:45 $\mathrm{kg} \mathrm{ha}^{-1}$ NPK. Jain and Poonia (2003) also observed similar finding.

Table.1 Cost of cultivation (for Agro practices) of per common cost of Cultivation fixed cost of all treatment

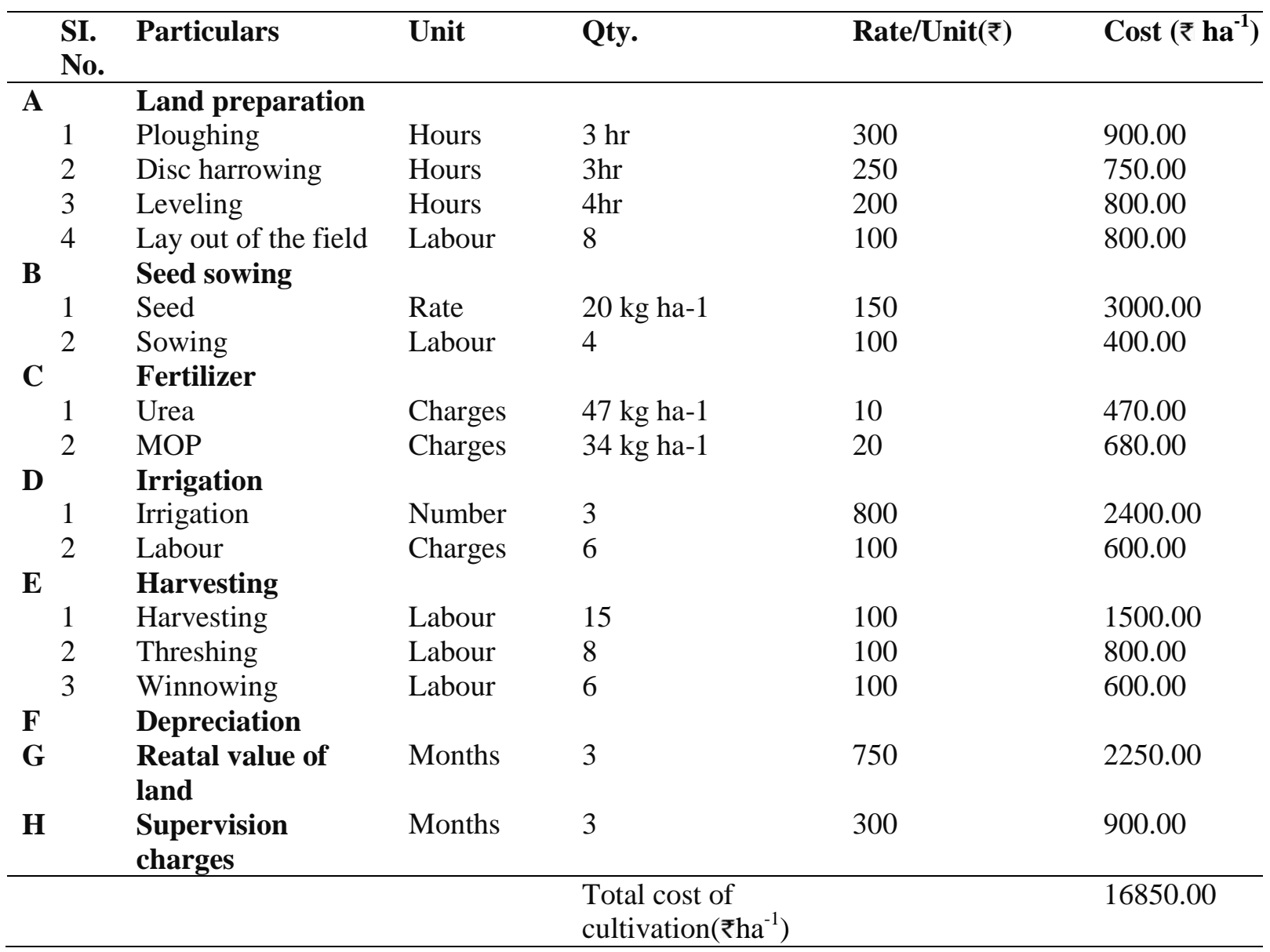


Table.2 Variable cost and cost of cultivation on each treatment

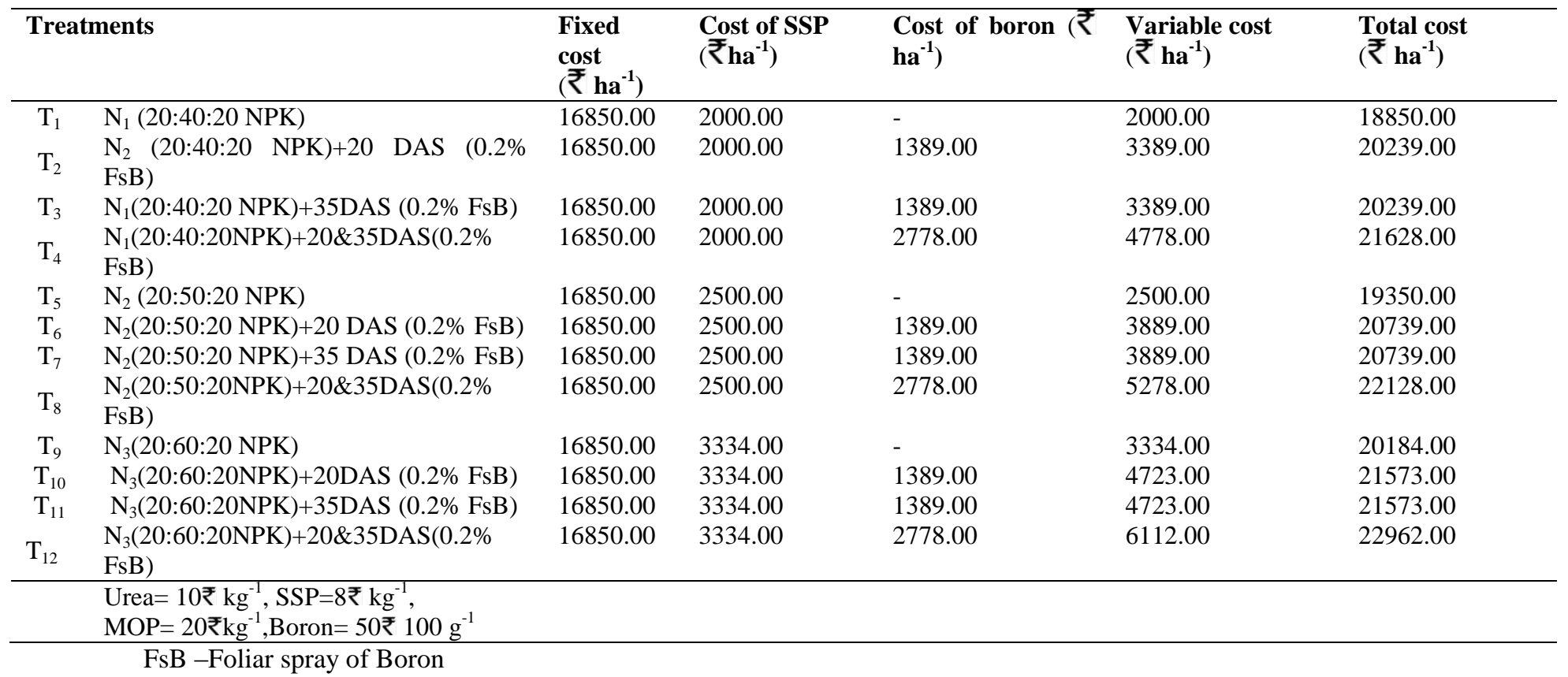

Table.3 Mean grain yield and straw yield grain and straw return and gross return

\begin{tabular}{|c|c|c|c|c|c|c|}
\hline \multicolumn{2}{|c|}{ Treatments } & \multicolumn{2}{|l|}{ Yield $\left(\mathrm{t} \mathrm{ha}^{-1}\right)$} & \multicolumn{2}{|c|}{ Return (₹ ha' ${ }^{-1}$ ) } & \multirow[t]{2}{*}{ Gross return $\left(₹\right.$ ha $\left.^{-1}\right)$} \\
\hline & & Grain yield & Straw yield & Grain & Straw & \\
\hline $\mathrm{T}_{1}$ & $\mathrm{~N}_{1}(20: 40: 20 \mathrm{NPK})$ & 0.99 & 2.06 & 45816.00 & 3109.50 & 48925.50 \\
\hline $\mathrm{T}_{2}$ & $\begin{array}{l}\mathrm{N}_{2}(20: 40: 20 \mathrm{NPK})+20 \text { DAS } \\
(0.2 \% \mathrm{FsB})\end{array}$ & 1.12 & 2.28 & 51566.00 & 3429.00 & 54995.00 \\
\hline $\mathrm{T}_{3}$ & $\begin{array}{l}\mathrm{N}_{1}(20: 40: 20 \quad \mathrm{NPK})+35 \mathrm{DAS} \\
(0.2 \% \text { FsB })\end{array}$ & 1.22 & 2.33 & 56120.00 & 3499.50 & 59619.50 \\
\hline $\mathrm{T}_{4}$ & $\begin{array}{l}\mathrm{N}_{1}(20: 40: 20 \mathrm{NPK})+20 \& 35 \mathrm{DA} \\
\mathrm{S}(0.2 \% \mathrm{FsB})\end{array}$ & 1.28 & 2.38 & 58880.00 & 3579.00 & 62459.00 \\
\hline $\mathrm{T}_{5}$ & $\mathrm{~N}_{2}(20: 50: 20 \mathrm{NPK})$ & 1.22 & 2.33 & 56120.00 & 3499.50 & 59619.50 \\
\hline $\mathrm{T}_{6}$ & $\begin{array}{l}\mathrm{N}_{2}(20: 50: 20 \quad \mathrm{NPK})+20 \text { DAS } \\
(0.2 \% \text { FsB })\end{array}$ & 1.34 & 2.46 & 61778.00 & 3699.00 & 65477.00 \\
\hline $\mathrm{T}_{7}$ & $\begin{array}{ll}\mathrm{N}_{2}(20: 50: 20 & \mathrm{NPK})+35 \\
(0.2 \% \mathrm{FsB}) & \mathrm{DAS}\end{array}$ & 1.36 & 2.67 & 62836.00 & 4009.50 & 66845.50 \\
\hline $\mathrm{T}_{8}$ & $\begin{array}{l}\mathrm{N}_{2}(20: 50: 20 \mathrm{NPK})+20 \& 35 \mathrm{DA} \\
\mathrm{S}(0.2 \% \mathrm{FsB})\end{array}$ & 1.33 & 2.67 & 61180.00 & 4009.50 & 65189.50 \\
\hline $\mathrm{T}_{9}$ & $\mathrm{~N}_{3}(20: 60: 20 \mathrm{NPK})$ & 1.24 & 2.43 & 57316.00 & 3645.00 & 60961.00 \\
\hline $\mathrm{T}_{10}$ & $\begin{array}{l}\mathrm{N}_{3}(20: 60: 20 \mathrm{NPK})+20 \mathrm{DAS} \\
(0.2 \% \mathrm{FsB})\end{array}$ & 1.35 & 2.48 & 62238.00 & 3729.00 & 65967.00 \\
\hline $\mathrm{T}_{11}$ & $\begin{array}{l}\mathrm{N}_{3}(20: 60: 20 \mathrm{NPK})+35 \mathrm{DAS} \\
(0.2 \% \mathrm{FsB})\end{array}$ & 1.62 & 2.85 & 74520.00 & 4275.00 & 78795.00 \\
\hline $\mathrm{T}_{12}$ & $\begin{array}{l}\mathrm{N}_{3}(20: 60: 20 \mathrm{NPK})+20 \& 35 \mathrm{DA} \\
\mathrm{S}(0.2 \% \mathrm{FsB})\end{array}$ & 1.40 & 2.69 & 64400.00 & 4039.50 & 68439.50 \\
\hline & $\begin{array}{l}\text { Sale rate of grain }=46 ₹ \mathrm{~kg}^{-1} \\
\text { Sale rate of straw }=1.5 ₹ \mathrm{~kg}^{-1}\end{array}$ & & & & & \\
\hline
\end{tabular}
FsB -Foliar spray of Boron 
Table.4 Total cost of cultivation $\left(₹ \mathrm{ha}^{-1}\right)$ gross return $\left(₹ \mathrm{ha}^{-1}\right)$ net return $\left(₹ \mathrm{ha}^{-1}\right)$ and Benefit cost ratio

\begin{tabular}{lllccc}
\hline S.No. & Treatments & $\begin{array}{l}\text { Cost of cultivation } \\
\left(₹ \mathbf{~ h a}^{-1}\right)\end{array}$ & $\begin{array}{c}\text { Gross return } \\
\left(₹ \text { ha }^{-1}\right)\end{array}$ & $\begin{array}{l}\text { Net } \\
\left(₹ \text { ha }^{-1} \text { ) }\right.\end{array}$ & $\begin{array}{l}\text { Beturn } \\
\text { cost ratio }\end{array}$ \\
\hline $\mathrm{T}_{1}$ & $\mathrm{~N}_{1}(20: 40: 20 \mathrm{NPK})$ & 18850.00 & 48925.50 & 30075.50 & 1.59 \\
$\mathrm{~T}_{2}$ & $\mathrm{~N}_{2}(20: 40: 20 \mathrm{NPK})+20 \mathrm{DAS}(0.2 \% \mathrm{FsB})$ & 20239.00 & 54995.00 & 34756.00 & 1.71 \\
$\mathrm{~T}_{3}$ & $\mathrm{~N}_{1}(20: 40: 20 \mathrm{NPK})+35 \mathrm{DAS}(0.2 \% \mathrm{FsB})$ & 20239.00 & 59619.50 & 39380.50 & 1.94 \\
$\mathrm{~T}_{4}$ & $\mathrm{~N}_{1}(20: 40: 20 \mathrm{NPK})+20 \& 35 \mathrm{DAS}(0.2 \% \mathrm{FsB})$ & 21628.00 & 62459.00 & 40831.00 & 1.88 \\
$\mathrm{~T}_{5}$ & $\mathrm{~N}_{2}(20: 50: 20 \mathrm{NPK})$ & 19350.00 & 59619.50 & 40269.00 & 2.08 \\
$\mathrm{~T}_{6}$ & $\mathrm{~N}_{2}(20: 50: 20 \mathrm{NPK})+20 \mathrm{DAS}(0.2 \% \mathrm{FsB})$ & 20739.00 & 65477.00 & 44738.00 & 2.15 \\
$\mathrm{~T}_{7}$ & $\mathrm{~N}_{2}(20: 50: 20 \mathrm{NPK})+35 \mathrm{DAS}(0.2 \% \mathrm{FsB})$ & 20739.00 & 66845.50 & 46106.50 & 2.22 \\
$\mathrm{~T}_{8}$ & $\mathrm{~N}_{2}(20: 50: 20 \mathrm{NPK})+20 \& 35 \mathrm{DAS}(0.2 \% \mathrm{FsB})$ & 22128.00 & 65189.50 & 43061.50 & 1.94 \\
$\mathrm{~T}_{9}$ & $\mathrm{~N}_{3}(20: 60: 20 \mathrm{NPK})$ & 20184.00 & 60961.00 & 40777.00 & 2.08 \\
$\mathrm{~T}_{10}$ & $\mathrm{~N}_{3}(20: 60: 20 \mathrm{NPK})+20 \mathrm{DAS}(0.2 \% \mathrm{FsB})$ & 21573.00 & 65967.00 & 44394.00 & 2.08 \\
$\mathrm{~T}_{11}$ & $\mathrm{~N}_{3}(20: 60: 20 \mathrm{NPK})+35 \mathrm{DAS}(0.2 \% \mathrm{FsB})$ & 21573.00 & 78795.00 & 57222.00 & 2.65 \\
$\mathrm{~T}_{12}$ & $\mathrm{~N}_{3}(20: 60: 20 \mathrm{NPK})+20 \& 35 \mathrm{DAS}(0.2 \% \mathrm{FsB})$ & 22962.00 & 68439.50 & 45477.50 & 1.98 \\
\hline
\end{tabular}

FsB -Foliar spray of Boron

\section{Cost of cultivation}

Maximum cost of cultivation (22962.00 ha $\left.{ }^{-1}\right)$ was recorded in treatment $\mathrm{T} 12$ i.e., $\mathrm{N} 3$ $(20: 60: 20 \mathrm{NPK})+20 \& 35 \mathrm{DAS}(0.2 \%$ foliar spray of borax), whereas the lowest value $\left(18850.00 \mathrm{ha}^{-1}\right)$ was observed in treatment $\mathrm{T} 1$ i.e., N1 (20:40:20 NPK). The results are in conformity with those of, Obeng et al., (2012), Singh et al., (2003) and Malik et al., (1990).

Gross return: Maximum gross return (78795.00 ha ${ }^{-1}$ ) was recorded in treatment T11 i.e., N3 (20:60:20 NPK) + (0.2\% foliar spray of borax) at 35 DAS, which was the lowest value (48925.00 ha $\mathrm{ha}^{-1}$ ) was observed in treatment T1 i.e., N1 (20:40:20 NPK). Naik et al., (1995) and Rathore et al., (2006) also observed similar finding.

\section{Net return}

Maximum net return (57222.00 $\mathrm{ha}^{-1}$ ) was recorded in treatment T11 i.e. N3 (20:60:20 $\mathrm{NPK})+(0.2 \%$ foliar spray of borax $)$ at 35 DAS, whereas the lowest value (30075.50 ha $\left.{ }^{-1}\right)$ was observed in treatment $\mathrm{T} 1$ i.e., $\mathrm{N} 1$
(20:40:20 NPK) and these are partially supporting by Pradhan et al., (2010) and Shaikh (1995).

\section{Benefit cost ratio}

Maximum benefit cost ratio (2:65) was recorded in treatment T11 i.e. N3 (20:60:20 $\mathrm{NPK})+(0.2 \%$ foliar spray of borax $)$ at 35 DAS, whereas the lowest value 1:59 was observed in treatment T1 i.e. N1 (20:40:20 NPK). The results are in conformity with those of, Totawat et al., (2001), Yadav and Solanki (2002), Panday et al., (2001). The probable reason for increase in economics of treatment $\mathrm{T} 11$ i.e., $\mathrm{N} 3(20: 60: 20 \mathrm{NPK})+$ ( $0.2 \%$ foliar spray of borax) at 35 DAS, due to high level of $\mathrm{P}+0.2 \%$ foliar spray of borax at 35DAS (pre flowering) through application of SSP and borax recorded higher net returns, $\mathrm{B}: \mathrm{C}$ ratio, protein content, $\mathrm{N}$ and $\mathrm{P}$ uptake and available phosphorus in soil in field pea than that of DAP and AMF are in the findings of Singh et al., (2005).

The highest gross return $\left(78795.00 \mathrm{ha}^{-1}\right)$, net return $\left(57222.00 \mathrm{ha}^{-1}\right)$ and benefit cost ratio (2.65) were registered in treatment T11- N3 
$(20: 60: 20 \mathrm{NPK})+0.2 \%$ foliar spray of borax at 35DAS (pre-flowering). Whereas the lowest value (48925.50 $\left.\mathrm{ha}^{-1}\right),(30075.50$ ha-1) and (1.59) respectively in the treatment $\mathrm{T} 1$ N1 (20:40:20 NPK).

\section{References}

Anonymous. 2010-2011. Annual Report All India Co-ordinated Pearlmillet Improvement Project pp.141-142.

Basavarajappa, et al. 2002. Response of safflower to bio-fertilizers with nitrogen levels on growth and seed yield.

Jain, N.K. and Poonia, B.L. 2003. Integrated nutrient management in pearlmillet and optimizing fertilizer requirement in succeeding wheat. Crop Res., 26(1): 62-66.

Malik, A.S., Singh, J. and Faroda, A.S. 1990. Effect of integrated agronomic practices on pearlmillet production under rainfed condition. Crop Res., 3: 21-26.

Naik, B., Linge Gowda, T.B.K., Thimme Gowda, S. and Sridhara, S. 1995. Effect of integrated nutrient management on growth and grain yield of foxtail millet (Setaria italica L. Beauv.) under rainfed conditions on Alfisols of sub-tropical India. Fertilizer News, 40(3): 55-57.

Panday, R.K., Maranville, J.W., and Bako, Y. 2001. Nitrogen Fertilizer Response and Efficiency for Three Cereal Crops in Niger. Communications in Soil Science and Plant Analysis, 32(9\&10): 1465-1482.

Pardhan, A., Rajput and Patel, 2010. Effect of varities and nitrogen levels on growth and yield of Kodo millet (Paspallum scrobiculatum L.) under rainfed condition. Ann. Agric. New service, 31(3\&4): 86-87.
Rathore, V.S., Singh, P. and Gautam, R.C. 2006. Productivity and water use efficiency of rainfed pearlmillet (Pennisetum glaucum L.) as influenced by planting patterns and integrated nutrient management. Indian $J$. Agronomy, 51(1): 46-48.

Shaikh, M. 1995. Genotype response of pearlmillet to planting date alternations and nitrogen application rates in a scarce rainfall shallow soil ecosystem. Crop Res., 10: 229235.

Singh, R., Singh, D.P., \& Tyagi, P.K. 2003. Effect of Azotobacter, Farmyard Manure and Nitrogen Fertilization on Productivity of Pearl Millet Hybrids (Pennisetum glaucum (L) R. $\mathrm{Br})$ in Semi-Arid Tropical Environment, GAGS, 49(1): 21-24.

Singh, R.C., Kumar, S., Kadian, V.S. and Singh, S.N. 2005. Effect of FYM and fertilizer along and their combination on yield of pearlmillet. Haryana Agricultural University J. Res., 35: 109-112.

Sonawane, P.D., Wadile, S.C., Girase, P.P., Chitodkar, S.S. and Sonawane, D.A. 2010. Response of summer pearlmillet (Pennisetum glauchum L.) to depth and time of irrigation. Scheduling. Int. J. Agri. Sci., 6(1): 283-285.

Tiwana, U.S. and Puri, K.P. 2005. Effect of nitrogen levels on the fodder yield and quality of pearl millet varieties under rainfed conditions. Forage Res. 31(2): 142-143.

Totawat, K.L., Somani, L.L., Singh, R. and Singh, G. 2001. Integrated nitrogen management in maize wheat cropping sequence on typic haplustalfs of western India. Annals of Arid Zone, 40(4): 439-444.

Yadava, N.S. and Solanki, N.S. 2002. Effect of levels of nitrogen and its time of application on fodder production of pearl millet. Forage Res., 28: 6-7.

\section{How to cite this article:}

Neha, Gautam Ghosh, Preeti Choudhary and Shobha Kumari. 2017. Economic (Benefit Cost Ratio) Status of Summer Pearlmillet at different NPK Levels. Int.J.Curr.Microbiol.App.Sci. 6(6): 1074-1079. doi: https://doi.org/10.20546/ijcmas.2017.606.124 